\title{
PERLINDUNGAN HUKUM TERHADAP PEMILIK LAGU YANG LAGUNYA DIUBAH TANPA IJIN
}

\author{
Komang Gede Pradnyan Supardi Yasa, Fakultas Hukum Universitas Udayana, \\ e-mail: komangpradnyan@yahoo.co.id \\ I Gede Agus Kurniawan, Fakultas Hukum Universitas Udayana, e-mail: \\ aguskurniawan2015@gmail.com
}

doi: https://doi.org/10.24843/KS.2020.v08.i11.p06

\begin{abstract}
ABSTRAK
Seiring perkembangan jaman banyak genre musik baru yang bermunculan, salah satunya adalah genre Koplo. Belakangan ini marak grup-grup musik yang mengubah genre dari Pop menjadi Koplo. Banyak dari grup-grup tersebut yang mengubah genre lagu tanpa seijin pencipta lagu tersebut sehingga kemudian muncul permasalahan Hak Cipta. Penelitian ini bertujuan untuk memberikan gambaran yang jelas mengenai bagaimana perlindungan hukum terhadap pencipta yang lagunya diubah tanpa seijin dari pencipta lagu tersebut dan bagaimana penyelesaian jika terjadinya sengketa terhadap lagu yang diubah tanpa seijin pencipta lagu. Penelitian ini menggunakan metode penelitian hukum Normatif, yang dimana metode penelitian ini mengkaji hukum sebagai suatu norma yang dimana terdapat kekaburan norma tentang perlindungan hukum. Hasil pembahasan dari penelitian ini yaitu pemegang Hak Cipta sudah mendapatkan perlindungan hukum sejak karyanya diwujudkan ke dalam bentuk nyata yang dimana hal tersebut sesuai dengan prinsip deklaratif. Meskipun sudah mendapatkan perlindungan sejak karyanya diwujudkan dalam bentuk nyata, sebaiknya jika dilakukan pencatatan terhadap hak cipta tersebut agar memiliki bukti yang formal. Penyelesaian sengketa terhadap Hak Cipta dapat diselesaikan melalui dua cara. Cara yang pertama melalui jalur non litigasi dan yang kedua melalui jalur litigasi. Penyelesaian melalui jalur no nlitigasi dibagi menjadi beberapa bagian yaitu Konsultasi, mediasi, negosiasi, konsiliasi, dan arbitrase. Sedangkan jika melalui jalur litigasi, dapat ditempuh melalui dua cara yaitu upaya perdata dan upaya pidana. Jika pelaku terbukti melakukan pelanggaran maka sanksi yang diterima dapat berupa kurungan dan denda sesuai yang tercantum didalam Undang-Undang Hak Cipta tersebut.
\end{abstract}

Kata Kunci : Hak Cipta, Perlindungan Hukum, Pengubahan lagu

\begin{abstract}
Along with the times, many new music genres have emerged, one of which is the Koplo genre. Lately, music groups are blooming which changed the genre from Pop songs to Koplo. Many of these groups have changed the song genre without the author's permission, so they appear later to become Copyright. The purpose of this study is to provide a clear picture of making laws about the creator whose song was changed without the author's permission and how to increase the refutation of the song that was changed without the author's permission. The method used in this study uses normative legal research methods, where this research method studies law as a norm that exists everywhere that is related to norms regarding legal protection. The result of this research discussion is that the Copyright holder has obtained legal protection because his work has been made in a form that is in accordance with declarative principles. Because it has been approved since the work was manifested in concrete form, copyright must be approved to have official proof. Settlement if there is a dispute about Copyright can be resolved in two ways. The first method is through non-litigation and the second is through litigation. Settlement through non-litigation is divided into several parts, namely Consultation, mediation, negotiation, conciliation, and arbitration. While through litigation, it can be continued in two ways, namely civil struggle and
\end{abstract}


struggle. If the lottery is proven, the penalty received can be in the form of confirmation and fines in accordance with the Copyright Act.

Key words : Copyright, Legal Protection, Song Changing

\section{Pendahuluan}

\subsection{Latar Belakang}

Kekayaan intelektual merupakan hasil kreativitas dari pikiran manusia dalam rangka untuk memenuhi kebutuhan serta kesejahteraan hidupnya. Konsep dari Kekayaan Intelektual pada dasarnya merupakan suatu bentuk penghargaan dari hasil kreativitas manusia, baik berupa penemuan ataupun hasil karya cipta dan seni. ${ }^{1}$ Hak Kekayaan Intelektual merupakan salah satu bagian dari hukum harta benda (hukum kekayaan) yang dikelompokkan sebagai suatu hak perseorangan yang sifatnya tidak berwujud dan bersifat abstrak jika dibandingkan dengan hak atas benda bergerak lainnya. Hak Cipta merupakan salah satu bagian dalam Kekayaan Intelektual yang mendapat perlindungan hukum, dimana menurut Pasal 1 Ketentuan Umum UndangUndang Nomor 28 tahun 2014 tentang Hak Cipta. Dimana dimaksud dengan Hak Cipta adalah hak eksklusif pencipta yang timbul secara otomatis berdasarkan prinsip deklaratif setelah suatu ciptaan diwujudkan dalam bentuk nyata tanpa mengurangi pembatasan sesuai dengan ketentuan peraturan perundang-undangan. Yang dimaksud dengan hak eksklusif ini adalah suatu hak yang diperuntukkan bagi pemegangnya, sehingga pemegang hak dapat mencegah dan melarang orang lain untuk meniru atau menggunakan hak kekayaan intelektualnya tanpa seizin pemegang hak.

Hak esklusif ini memiliki dua muatan yaitu yang pertama adalah hak ekonomi untuk mendapatkan keuntungan dan untuk perolehan pengakuan hak berupa pengalihan dan pemberian izin menggunakan hak kekayaan intelektualnya dengan tujuan untuk memperoleh royalti serta hak moral yang melekat pada diri pemilik hak tersebut yang tidak dapat dialihkan dan bersifat tetap. Menurut Pasal 8 UndangUndang Nomor 28 Tahun 2014 tentang Hak Cipta "Hak ekonomi merupakan hak eksklusif Pencipta atau Pemegang Hak Cipta untuk mendapatkan manfaat ekonomi atas Ciptaan". Sedangkan untuk pengertian hak moral dijelaskan pada Pasal 5 yaitu hak yang melekat secara abadi pada diri si pencipta untuk mencantumkan namanya sehubungan dengan pemakaian ciptaannya untuk umum, mengubah ciptaannya, dan untuk mempertahankan haknya jika terjadi hal-hal yang merugikan kehormatannya. ${ }^{2}$ Fungsi dari Hak Cipta disini adalah untuk melindungi hasil kecerdasan, pikiran, dan renungan seseorang yang pada suatu hari akan menjadi sebuah karya seperti film, musik ataupun buku. ${ }^{3}$ Objek yang mendapat perlindungan dari hak cipta yaitu adalah ilmu pengetahuan, seni, dan sastra. Salah satu objek hak cipta yang terdapat di dalam seni yaitu musik atau lagu. Hampir seluruh kalangan di dunia ini dari anak-anak hingga dewasa yang senang mendengarkan musik atau lagu. Menurut al-Suhrawardi, musik bagi sebagian orang dapat berfungsi sebagai penyembuh, dan penyejuk jiwa

1 Dewi, Anak Agung Mirah Satria. "Perlindungan Hukum Hak Cipta Terhadap Cover Version Lagu Di Youtube." Jurnal Magister Hukum Udayana (Udayana Master Law Journal) 6, no. 4 (2017): 508-520.

2 Lihat pasal 5 ayat (1) Undang-Undang Nomor 28 Tahun 2014 Tentang Hak Cipta

3 Goldstein, Paul. Hak Cipta: Dahulu, Kini dan Esok. Yayasan Obor Indonesia, 1997. 
manusia. ${ }^{4}$ Jika berbicara tentang musik atau lagu di tanah air maka tidak akan ada habisnya. Dari tahun 90an lagu sudah menjadi hiburan bagi masyarakat di kota maupun daerah, kalangan muda atau tua sebagian besar senang mendengarkan musik. Banyak musisi-musisi tanah air yang melambungkan namanya hingga ke kancah internasional. Seiring dengan berkembangnya jaman, genre dari musik atau lagu sendiri sudah sangat beragam. Banyak terdapat berbagai jenis aliran musik didunia ini seperti Pop, Dangdut, Reggae, Hardcore, Indie, Koplo, Electronic Dj dan lain sebagainya.

Belakangan ini di kalangan anak muda khususnya di Bali tengah muncul kegemararan terhadap aliran musik koplo. Jika dilihat dari sejarahnya aliran musik ini tidak serta merta muncul begitu saja. Banyak proses yang dilalui sehingga membentuk aliran musik koplo yang dapat didengarkan seperti saat ini. Akar dari musik koplo ini adalah aliran musik dangdut, dimana orang-orang tahun 90an sangat suka mendengar dan menari bersama diiringi musik dangdut. Kemudian masuk ke tahun 2000an banyak penikmat dangdut yang sudah mulai bosan mendengar musik dangdut yang asli. Oleh karena itu musisi di Jawa Timur, terutama di pesisir Pantai Utara (Pantura) mengembangkan dangdut koplo. Perbedaan antara dangdut koplo dan dangdut yang asli adalah penambahan kendang kempul, yaitu musik etnik yang berasal dari Banyuwangi, Jawa Timur. Penambahan kendang kempul inilah yang menyebabkan aliran musik koplo asik didengarkan oleh masyarakat khususnya kalangan muda sehingga memiliki banyak penggemar.

Perkembangan zaman ini tentu memberikan dampak positif dan negatif terkait mendengarkan musik/lagu yang diubah menyesuaikan dengan zaman. ${ }^{5}$ Dampak positifnya adalah masyarakat khususnya kalangan muda dapat berkreasi sesuai keahlian dan kertertarikannya untuk menikmati musik yang sesuai dengan jiwa dan selera mereka. ${ }^{6}$ Selain dampak positif, muncul dampak negatif yaitu maraknya pembajakan hak cipta sebagai akibat dari perkembangan teknologi sehingga dengan mudahnya untuk memindahkan karya-karya cipta orang lain ke dalam bentuk yang berbeda tanpa diketahui oleh pemilik karya tersebut dan membuat semakin marak orang yang justru menyalahgunakan lagu orang lain demi kepentingan pribadi seperti mengedit atau mengubah lagu orang lain untuk mendapat keuntungan pribadi. ${ }^{7}$ Belakangan ini marak grup-grup musik yang berlomba mengubah lagu dari aliran musik pop ke aliran musik koplo karena daya tarik peminatnya yang begitu besar. Banyak dari grup-grup tersebut yang mengubah genre musik dari genre pop ke genre koplo. Tidak jarang beberapa pelaku yang mengubah lagu orang lain tersebut pada akhirnya mendapatkan popularitas yang melebihi pemilik lagu asli nya, sehingga mereka bisa mendapatkan keuntungan pribadi melalui tindakan mengubah lagu orang lain dan bahkan mendapat tawaran untuk tampil menyanyikan lagu yang diubah tersebut, tetapi sebagian dari pelaku tersebut tidak meminta izin kepada pemilik atau

4 Julia, J. Pendidikan Musik: Permasalahan dan Pembelajarannya. UPI Sumedang Press, 2017.

5 Swari, P. Dina Amanda, and I. Made Subawa. "Perlindungan Hukum Lagu Yang Diunggah Tanpa Izin Pencipta Di Situs Youtube." Kertha Semaya: Journal Ilmu Hukum 6, no. 10 (2018): 115.

6 Dimyati, Agus. "Tinjauan Yuridis Terhadap Perlindungan Hak Cipta Dalam Penggunaan Karya Cipta Musik Dan Lagu Karaoke." Hukum Responsif Jurnal Hukum 7, no. 1 (2018).

7 Utama, Arya, Titin Titawati, And Aline Febryani Loilewen. "Perlindungan Hukum Terhadap Hak Cipta Lagu Dan Musik Menurut Undang-Undang Nomor 28 Tahun 2004." Ganec Swara 13, no. 1 (2019): 78-83. 
pemegang Hak Cipta dari lagu tersebut sehingga kemudian menimbulkan permasalahan terhadap Hak Cipta.

Dalam beberapa artikel yang menulis mengenai Hak Cipta dijelaskan tentang bagaimana perlindungan hukum terhadap Hak Cipta lagu dengan berbagai objek penelitian, namun secara eksplisit hanya menjelaskan mengenai Hak Cipta secara umum yang dalam pemberlakuannya masih terdapat banyak permasalahan terkait dengan praktik hukum keperdataan. Sebelumnya telah terdapat dua penelitian serupa yang membahas mengenai perlindungan hukum Hak Cipta Lagu yang berjudul "Perlindungan Hukum Hak Cipta Terhadap Pencipta Lagu Yang Diunduh Melalui Internet" yang ditulis oleh Putu Dina Amanda Swari, yang lebih mengkhusus membahas mengenai alur pendaftaran hak cipta lagu. Serta penelitian yang berjudul "Upaya Hukum Penyelesaian Sengketa Karya Cipta Musik" yang ditulis oleh Ade Hendra Yasa, dimana penelitian ini lebih khusus membahas tentang upaya hukum penyelesaian sengketa karya cipta musik. Dalam tulisan ini penulis mencoba untuk meninjau dan mengkaji lebih lanjut mengenai perlindungan hukum terhadap pencipta lagu yang dalam penyajian lagunya, mereka yang berkepentingan mengubah susunan nada, lirik dan bahkan mengubah genre dari lagu aslinya serta konsekuensi hukum yang akan timbul jika hal tersebut dilakukan. Pembahasan yang akan dibahas dalam tulisan ini, lebih menjurus ke dalam perlindungan hukum yang diterima dan didapat oleh pemilik atau pemegang Hak Cipta lagu yang pada artikel lain belum ada yang membahas tentang pembahasan ini. Diharapkan dengan adanya tulisan ini, orang lain lebih menghormati dan menghargai hasil karya dari orang lain, dan lebih mengetahui perlindungan hukum yang diatur di dalam Undang-Undang Hak Cipta.

\subsection{Rumusan Masalah}

1. Bagaimanakah perlindungan hukum terhadap pencipta lagu yang karyanya diubah tanpa ijin atau perjanjian resmi?

2. Bagaimanakah penyelesaian jika terjadinya sengketa terhadap lagu yang diubah tanpa seijin pencipta lagu?

\subsection{Tujuan Penelitian}

Tujuan dari dibuatnya penelitian ini untuk memberikan gambaran yang jelas mengenai bagaimana perlindungan hukum terhadap pencipta lagu yang lagunya diubah tanpa ijin dan bagaimana penyelesaian hukum jika terjadi sengketa terhadap lagu yang diubah tanpa seijin dari pencipta lagu serta sanksi apa saja yang diterima jika terbukti melakukan tindak pelanggaran terhadap Hak Cipta tersebut.

\section{Metode Penelitian}

Penelitian ini menggunakan metode penelitian hukum normatif. Metode penelitian ini mengkaji hukum sebagai suatu norma. ${ }^{8}$ Dimana terdapat kekaburan norma tentang perlindungan hukum terhadap pencipta lagu yang dimana lagu tersebut diubah tanpa seijin pencipta lagu. Bahan penulisan yang dikumpulkan yaitu mencakup bahan hukum primer berupa Peraturan Perundang-undangan yang berlaku dan bersifat mengikat, bahan hukum sekunder yaitu berupa tulisan dari para ahli yang tercantum di dalam literatur-literatur, serta bahan hukum tersier yang meliputi media

8 Pratista, I. Gusti Putu Andre, and Ida Ayu Sukihana. "Pelanggaran Hak Moral Karya Lagu/Musik dan Rekaman Suara dalam Praktik Penggunaan Hak Cipta." Kertha Semaya: Journal Ilmu Hukum (2014). 
informasi serta bahan tertulis lain yang sesuai dengan permasalahan yang dibahas di dalam penelitian ini. ${ }^{9}$

\section{Hasil dan Pembahasan}

\subsection{Perlindungan Hukum Terhadap Pencipta Yang Lagunya Diubah Tanpa Seijin Pencipta Lagu}

Musik atau lagu merupakan salah satu objek dari kekayaan intelektual dimana perlindungannya diatur pada Undang-Undang Hak Kekayaan Intelektual. ${ }^{10}$ Setiap orang yang ingin mengedit, mengubah, memperbanyak atau mengcover karya lagu seseorang wajib meminta ijin kepada pemilik atau pencipta lagu tersebut melalui perjanjian yang resmi. Perlindungan terhadap hak kekayaan intelektual seseorang sama pentingnya dengan perlindungan terhadap kepentingan ekonomi terutama dalam pandangan internasional. ${ }^{11}$ Undang-Undang Hak cipta menyatakan bahwa perlindungan terhadap Hak cipta lagu atau musik berlaku seumur hidup bagi pencipta lagu, dihitung sejak pertama kali diumumkan dan berlangsung selama 70 (tujuh puluh) tahun sejak pencipta meninggal dunia, terhitung sejak tanggal 1 Januari setelahnya. ${ }^{12}$

Perlindungan hukum memiliki arti yaitu suatu perlindungan yang diberikan oleh peraturan perundang-undangan yang ditujukan kepada subyek-subyek hukum sehingga dapat menikmati hak-hak yang diberikan oleh hukum. Pemilik lagu atau pemegang Hak Cipta lagu memiliki hak yang disebut Hak Moral dan Hak Ekonomi yang perlindungannya telah diatur di dalam Undang-Undang Hak Cipta. Hak Moral merupakan hak yang melekat pada diri si pencipta dan tidak dapat dihapus atau dihilangkan meskipun Hak Ciptanya telah dialihkan. Sedangkan Hak Ekonomi menurut Pasal 8 Undang-Undang Nomor 28 Tahun 2014 tentang Hak Cipta yaitu "Hak ekonomi merupakan hak eksklusif Pencipta atau Pemegang Hak Cipta untuk mendapatkan manfaat ekonomi atas Ciptaan". Terkait tentang genre/lagu yang diubah, Pemilik atau pemegang Hak Cipta dari lagu tersebut memiliki hak untuk pempertahankan dan melindungi ciptaannya, sesuai dengan yang dijelaskan didalam pasal 5 huruf (e) Undang-Undang Nomor 28 Tahun 2014 Tentang Hak Cipta "Pencipta berhak untuk mempertahankan haknya dalam hal terjadi distorsi Ciptaan, mutilasi Ciptaan, modifikasi Ciptaan, atau hal yang bersifat merugikan kehormatan diri atau reputasinya." Terkait dengan lagu yang diubah tersebut, sudah tentu harus mengetahui terlebih dahulu apa tujuan dari mengubah genre dari lagu orang lain tersebut. Jika tujuannya untuk mendapatkan keuntungan pribadi, tentu harus mendapatkan ijin terlebih dahulu dari pemilik lagu tersebut dan jika tidak memiliki ijin Undang-Undang Hak Cipta telah mengatur hal tersebut, yaitu tercantum didalam Pasal 9 ayat (2), dan (3) Undang-Undang Nomor 28 Tahun 2014 tentang Hak Cipta :

(2) "Setiap Orang yang melaksanakan hak ekonomi sebagaimana dimaksud pada ayat wajib mendapatkan izin Pencipta atau Pemegang Hak Cipta."

9 Assa, Marybella Natasha. "Upaya Perlindungan Hukum Terhadap Hak Cipta Lagu dan Musik di Internet Menurut Undang-Undang Nomor 28 Tahun 2014." Lex Privatum 4, no. 1 (2016).

10 Dimyati, Agus. "Tinjauan Yuridis Terhadap Perlindungan Hak Cipta Dalam Penggunaan Karya Cipta Musik Dan Lagu Karaoke." Hukum Responsif Jurnal Hukum 7, no. 1 (2018).

11 Indriani, Iin. "Hak Kekayaan Intelektual: Perlindungan Hukum Terhadap Hak Cipta Karya Musik." Jurnal Ilmu Hukum 7, no. 2 (2018): 246-263.

12 Lihat pasal 58 ayat (1) dan (2) Undang-Undang Nomor 28 Tahun 2014 
(3) "Setiap Orang yang tanpa izin Pencipta atau Pemegang Hak Cipta dilarang melakukan Penggandaan dan/atau Penggunaan Secara Komersial Ciptaan."

Pasal 1 ayat (1) Undang-Undang Nomor 28 Tahun 2014 menyatakan bahwa "hak cipta adalah hak eksklusif pencipta yang timbul secara otomatis berdasarkan prinsip deklaratif setelah suatu ciptaan diwujudkan dalam bentuk nyata tanpa mengurangi pembatasan sesuai dengan ketentuan peraturan perundang-undangan". Dimana pengertian dari prinsip deklaratif adalah prinsip yang menyatakan bahwa ciptaan memiliki perlindungan sejak publikasinya selesai dibuat, diketahui, didengar, dan dilihat oleh orang lain. Karena itu, masalah antara pendaftaran hak cipta dan perlindungan hak cipta harus diikuti oleh sistem deklaratif.

Berdasarkan pasal 64 ayat (2) Undang-Undang No. 28 Tahun 2014 tentang Hak Cipta disebutkan bahwa pencatatan hak ciptaan bukanlah suatu kewajiban dan bersifat tidak mutlak. Perlindungan terhadap hasil karya hak cipta disini menganut sistem otomatis, dimana yang berarti didapatkan oleh si pencipta secara otomatis tanpa melalui proses pencatatan. Pencipta lagu telah mendapatkan perlindungan hukum setelah karya ciptaannya sudah berwujud dalam bentuk karya yang nyata. Konsep perlindungan otomatis ini didasarkan oleh salah satu prinsip dari Konvensi Berne yaitu Automatically Protection yang arti dari konsep ini adalah boleh didaftarkan atau tidak. ${ }^{13}$ Sistem Kekayaan Intelektual merupakan Hak Privat (private rights), yang artinya seseorang bebas untuk mengajukan permohonan atau mendaftarkan karya intelektualnya atau tidak.

Meskipun bersifat otomatis atau diperoleh sejak ciptaannya diwujudkan dalam bentuk yang nyata, akan lebih baik jika dilakukan pencatatan terhadap hak cipta tersebut. Tujuan dari proses pencatatan ini adalah jika terjadi tindak pelanggaran dari karya cipta dari si pencipta tersebut, agar lebih mudah untuk mebuktikan haknya serta lebih mudah mengajukan tuntuan karena terdapat bukti yang formal. Tujuan lain dari proses pencatatan ini adalah untuk mendapatkan kepastian hukum karena jika sudah didaftarkan, dapat diketahui dengan mudah siapa pemegang hak cipta tersebut. Sertifikat pendaftaran bukan menjadi bukti kepemilikan yang sah tentang adanya Hak Kekayaan Intelektual jika dapat dibuktikan sebaliknya. ${ }^{14}$

Sebagai contoh terhadap pelanggaran Hak Moral dan Hak Ekonomi pencipta atau pemilik Hak Cipta, dapat dilihat pada kasus antara Jerinx dan Via Vallen serta kasus antara Label Musik Nagaswara dengan Gen Halilintar. Via Vallen melakukan pelanggaran dengan mengubah genre dan mengcover lagu "Sunset di Tanah Anarki" yang diciptakan oleh Jerinx tanpa ijin terlebih dahulu dan dinyanyikan disebuah acara lalu direkam dan dibuatkan VCD dan disebarluaskan di masyarakat. Tetapi dari pihak Jerinx belum ada tindakan untuk melaporkan kasus tersebut melainkan hanya perang di Social Media. Sedangkan Gen Halilintar, mengubah lirik dan genre dari lagi "Lagi Syantik" yang dinyanyikan oleh Siti Badriyah dibawah naungan Label Musik Nagaswara dan mengcover lagu tersebut lalu mempublikasikannya di aplikasi video Youtube tanpa seijin pemilik lagu. Penyelesaian kasus ini yaitu pihak Nagaswara menempuh upaya perdata untuk meminta ganti rugi kepada pihak Gen Halilintar. Jika dilihat dari kasus tersebut, Via Vallen dan Gen Halilintar melakukan pelanggaran

13 Supasti, Ni Ketut. "Relevansi Hak Kekayaan Intelektual Dengan Hak Asasi Manusia Generasi Kedua." Jurnal Dinamika Hukum 14, no. 3 (2014): 518-527.

14 Kurniawan, I. Gede Agus. "Pengaturan Penghentian Pemakaian Indikasi Geografis Pada Merek Terdaftar Oleh Pihak Lain Yang Tidak Berhak (Studi Komparatif Beberapa Negara)." Jurnal Magister Hukum Udayana (Udayana Master Law Journal) 2, no. 2 (2013). 
yang sama yaitu sama-sama mengedit atau mengubah lagu dan mengcover lagu orang lain tanpa meminta ijin terlebih dahulu. Hal tersebut tentu melanggar Hak Moral dan Hak Ekonomi dari pencipta atau pemilik Hak Cipta dari lagu tersebut dan hal tersebut telah diatur di dalam Undang-Undang Hak Cipta. Sebagai public figure, seharusnya Via Vallen dan Gen Halilintar memiliki etika untuk meminta ijin terlebih dahulu serta menghormati karya orang lain karena karya tersebut terlahir dari ide dan kreativitas seseorang yang mungkin memiliki arti atau makna yang dalam dari ciptaannya tersebut. Dan sudah seharusnya pemilik Hak Cipta dari lagu tersebut mendapatkan royalty terkait dengan lagunya yang dinyanyikan oleh orang lain.

Hukum diciptakan sebagai suatu sarana untuk mengatur hak dan kewajiban dari subyek hukum. Menurut pendapat Sudikno Mertokusumo, hukum memiliki fungsi sebagai perlindungan bagi kepentingan manusia. ${ }^{15}$ Maka dari itu jika ingin manusia terlindungi, hukum harus bisa dilaksanakan. Setiap ciptaan seseorang, kelompok ataupun badan hukum haruslah dilindungi oleh Undang-Undang karena pada ciptaan itu secara otomatis melekat hak cipta yang sudah seharusnya dihormati oleh orang lain. ${ }^{16}$ Hukum dalam hal ini berfungsi untuk memberikan perlindungan mengenai hubungan antara hasil karya cipta dengan si pencipta atau pemilik Hak Cipta karya tersebut. Adanya kejelasan dari hukum itu sendiri dapat memberikan kemudahan pada penegakan hukum jika terjadinya pelanggaran terhadap hak cipta tersebut.

\subsection{Penyelesaian Sengketa Terhadap Lagu Yang Diubah Tanpa Seijin Pencipta Lagu}

Sengketa merupakan kondisi dimana terjadinya konflik antara individu atau kelompok yang memiliki hubungan serta kepentingan yang sama atas objek kepemilikan yang menimbulkan akibat hukum antara satu dan lainnya. Di jaman sekarang, marak terjadi masyarakat yang mengubah lagu atau musik orang lain sesuai selera mereka tanpa meminta ijin kepada si pencipta lagu. Hal ini yang menyebabkan kerugian kepada si pencipta lagu karena lagu yang ia ciptakan digunakan tanpa ijin oleh orang lain untuk mendapatkan keuntungan pribadi. Ini menyebabkan dapat terjadinya sengketa antara si pencipta lagu dengan orang lain yang mengubah musik atau lagu tersebut. Jika si pencipta lagu merasa dirugikan oleh tindakan tersebut, jalan keluar yang dapat ditempuh oleh si pencipta lagu tersebut adalah upaya penyelesaian sengketa. Penyelesaian sengketa disini merupakan suatu penyelesaian sebuah perkara yang dilakukan antara pihak satu dengan pihak lainnya. ${ }^{17}$ Berdasarkan pasal 95 ayat (1) Undang-Undang No. 28 Tahun 2014 disebutkan: "Penyelesaian sengketa Hak Cipta dapat dilakukan melalui alternatif penyelesaian sengketa, arbitrase, atau pengadilan".

Alternative dispute resolution atau Alternatif penyelesaian sengketa adalah upaya penyelesaian sengketa yang dilakukan diluar pengadilan atau yang disebut dengan non litigasi. Berdasarkan Undang-Undang Nomor 30 Tahun 1999 yang mengatur tentang Arbitrase dan Alternatif Penyelesaian Sengketa menyebutkan bahwa

15 Fuad, Matari Nurfirdausyi. "KEPASTIAN HUKUM BAGI KONSUMEN TERHADAP KERUGIAN YANG DITIMBULKAN OLEH DRIVER GO-JEK BERDASARKAN HUKUM PERLINDUNGAN KONSUMEN." LITIGASI 19, no. 1 (2019).

${ }^{16}$ Lopes, Fransin Miranda. "Penegakan Hukum Terhadap Pelanggaran Hak Cipta di Bidang Musik dan Lagu." Lex Privatum 1, no. 2 (2013).

17 Yasa, Ade Hendra, and AA Ketut Sukranatha. "UPAYA HUKUM PENYELESAIAN SENGKETA KARYA CIPTA MUSIK." Kertha Semaya: Journal Ilmu Hukum 4, no. 3. 
penyelesaian sengketa diluar pengadilan dapat dibagi menjadi beberapa bagian yaitu konsultasi, mediasi, negosiasi, konsiliasi, dan arbitrase. ${ }^{18}$

1. Konsultasi

Konsultasi merupakan proses penyelesaian sengketa yang bersifat personal antara satu pihak yang disebut klien dengan pihak lain yang disebut konsultan yang dimana konsultan memberikan pendapatnya kepada klien untuk memenuhi kebutuhan dan keperluan kliennya.

2. Mediasi

Mediasi merupakan proses penyelesaian sengketa antara satu pihak dengan pihak lainnya yang dilakukan dengan dibantu oleh mediator atau orang ketiga yang netral dan tidak memihak dimana keputusan untuk mencapai kesepakatan tetap berdasarkan kesepakatan Bersama para pihak, bukan mediator.

3. Negosiasi

Negosiasi merupakan proses penyelesaian sengketa yang dilakukan melalui cara musyawarah atau diskusi secara langsung dengan para pihak yang bersengketa, dan hasilnya bisa diterima oleh para pihak tersebut.

4. Konsiliasi

Konsiliasi merupakan proses penyelesaian sengketa dimana melibatkan orang ketiga yang bersifat netral untuk berkomunikasi dengan para pihak yang bersengketa, dimana dilakukan ditempat yang terpisah guna mengurangi ketegangan antara para pihak dan mengusahakan tercapainya kesepakatan antara para pihak untuk persetujuan penyelesaian sebuah sengketa.

5. Arbitrase

Arbitrase merupakan cara penyelesaian sengketa diluar pengadilan yang didasarkan pada perjanjian arbitrase yang dibuat secara tertulis oleh para pihak yang bersengketa. Berbeda dengan alternatif penyelesaian sengketa lainnya, arbitrase memiliki karakteristik yang menyerupai penyelesaian sengketa adjudikatif, dimana sengketa dalam arbitrase diputus oleh arbiter atau majelis arbiter dan putusan arbitrase tersebut bersifat final.

Selain penyelesaian sengketa diluar pengadilan atau non litigasi, terdapat juga penyelesaian sengketa hak cipta dimana penyelesaiannya dilakukan didalam pengadilan atau yang disebut dengan litigasi. ${ }^{19}$ Upaya penyelesaian terhadap sengketa Hak Cipta dapat ditempuh melalui dua cara, yaitu:

1. Upaya perdata

Berdasarkan pasal 1365 Kitab Undang-Undang Hukum Perdata, menyatakan bahwa setiap perbuatan melanggar hukum, yang menyebabkan kerugian mewajibkan orang yang karena salahnya membawa kerugian bagi orang lain, untuk mengganti kerugian tersebut.

Sesuai yang tercantum pada pasal 96 Undang-Undang Hak Cipta mengatur bahwa :

18 Lihat pasal 1 Undang-Undang Nomor 30 Tahun 1999 tentang Arbitrase dan Alternatif Penyelesaian Sengketa

19 Septiana, Kadek Irman, and AA Gede Oka Parwata. "PERLINDUNGAN HUKUM TERHADAP PENCIPTA LAGU YANG LAGUNYA DINYANYIKAN TANPA IJIN BERDASARKAN UNDANGUNDANG HAK CIPTA." Kertha Semaya: Journal Ilmu Hukum 7, no. 2: 1-12.. 
1) "Pencipta, pemegang Hak Cipta dan/atau pemegang Hak Terkait atau ahli warisnya yang mengalami kerugian hak ekonomi berhak memperoleh Ganti Rugi."

2) "Ganti Rugi sebagaimana dimaksud pada ayat (1) diberikan dan dicantumkan sekaligus dalam amar putusan pengadilan tentang perkara tindak pidana Hak Cipta dan/atau Hak Terkait."

3) "Pembayaran Ganti Rugi kepada Pencipta, Pemegang Hak Cipta dan/atau pemilik Hak Terkait dibayarkan paling lama 6 (enam) bulan setelah putusan pengadilan yang berkekuatan hukum tetap."

Kemudian dalam Pasal 97 Undang-Undang Hak Cipta menyebutkan bahwa:

1) "Dalam hal Ciptaan telah dicatat menurut ketentuan Pasal 69 ayat (1), pihak lain yang berkepentingan dapat mengajukan gugatan pembatalan pencatatan Ciptaan dalam daftar umum Ciptaan melalui Pengadilan Niaga."

2) "Gugatan sebagaimana dimaksud pada ayat (1) ditujukan kepada Pencipta dan atau Pemegang Hak Cipta terdaftar."

Pada pasal 97 ayat (1) Undang-Undang Hak Cipta mengatur mengenai Pengadilan yang memiliki wewenang untuk mengadili sengketa ini adalah pengadilan Niaga. Selain daripada pengadilan Niaga, pengadilan lain tidak berwenang untuk menangani penyelesaian sengketa Hak Cipta. Untuk upaya perdata ini, hanya menitiberatkan beban ganti rugi kepada pelanggar karena menyebabkan kerugian bagi orang lain.

\section{Upaya pidana}

Dilihat pada pasal 9 ayat (1), (2), (3) Undang-Undang Nomor 28 Tahun 2014 mengatur bahwa :

1) "Pencipta atau Pemegang Hak Cipta sebagaimana dimaksud dalam Pasal 8 memiliki hak ekonomi untuk melakukan :
a) Penertiban ciptaan ;
b) Penggandaan ciptaan dalam segala bentuknya ;
c) Penerjemahan Ciptaan ;
d) Pengadaptasian, pengaransemenan, atau pentransformasian Ciptaan ;
e) Pendistribusian Ciptaan atau salinannya ;
f) Pertunjukan Ciptaan ;
g) Pengumuman Ciptaan ;
h) Komunikasi Ciptaan ; dan
i) Penyewaan Ciptaan

2) "Setiap orang yang melaksanakan hak ekonomi sebagaimana dimaksud pada ayat (1) wajib mendapatkan Izin Pencipta atau Pemegang Hak Cipta."

3) "Setiap orang yang tanpa izin Pencipta atau Pemegang Hak Cipta dilarang melakukan Penggandaan dan/atau Penggunaan Secara Komersial Ciptaan."

Terkait dengan isi dari pasal diatas, pada ayat (2) dan (3) dijelaskan bahwa setiap orang wajib mendapatkan izin dari Pencipta atau Pemegang Hak Cipta jika ingin melaksanakan hak ekonomi lagu tersebut. Yang artinya setiap orang dilarang untuk melakukan penggandaan atau penggunaan secara komersial jika tidak mendapatkan izin dari pencipta lagu. Jika ada yang melanggar, Pencipta dapat mengambil jalan upaya pidana untuk melaporkan tindak pelanggaran tersebut. Dan jika terbukti adanya suatu pelanggaran, maka orang yang melakukan pelanggaran tersebut akan menerima sanksi baik sanksi denda maupun pidana. Mengenai sanksi sebagai akibat dari suatu pelanggaran Hak Cipta tersebut, Pasal 113 ayat (1) dan (2) Undang-Undang 
No. 28 Tahun 2014 telah mengatur mengenai sanksi hukum pidana terkait dengan pelanggaran terhadap Hak Cipta Lagu yaitu :

1) "Setiap Orang yang dengan tanpa hak melakukan pelanggaran hak ekonomi sebagaimana dimaksud dalam Pasal 9 ayat (1) huruf i untuk Penggunaan Secara Komersial dipidana dengan pidana penjara paling lama 1 (satu) tahun dan/atau pidana denda paling banyak Rp100.000.000 (seratus juta rupiah)."

2) "Setiap Orang yang dengan tanpa hak dan/atau tanpa izin Pencipta atau pemegang Hak Cipta melakukan pelanggaran hak ekonomi Pencipta sebagaimana dimaksud dalam Pasal 9 ayat (1) huruf $c$, huruf $d$, huruf $f$, dan/atau huruf $h$ untuk Penggunaan Secara Komersial dipidana dengan pidana penjara paling lama 3 (tiga) tahun dan/atau pidana denda paling banyak Rp500.000.000,00 (lima ratus juta rupiah)."

Penyelesaian sengketa melalui upaya pidana dinilai lebih efektif jika dibandingkan dengan upaya perdata, karena upaya perdata hanya menitiberatkan ke bagian ganti rugi saja, sedangkan untuk upaya pidana sangat jelas memberikan sanksi baik sanksi kurungan maupun sanksi denda. Hal ini bertujuan untuk memberikan efek jera kepada si pelaku pelanggaran Hak Cipta sehingga tidak mengulangi perbuatannya. Salah satu contoh penyelesaian sengketa melalui upaya perdata yaitu pada kasus penyelesaian sengketa lagu "Sama Gilanya". PT. Bintang Puspita, telah merekam dan mengedarkan ulang, dengan cover baru lagu "Sama Gilanya", ciptaan Syam Permana, yang dinyanyikan oleh Tuti Wibowo, tanpa sepengetahuan Syam Permana, sebagai pencipta lagu tersebut. Kasus tersebut, akhirnya diselesaikan secara damai, atas bantuan PAPPRI, selaku organisasi pengayom para artis dan pencipta. Syam Permana, menerima kompensasi sebesar Rp. 250.000,- (dua ratus lima puluh ribu rupiah) dari PT. Bintang Puspita.

\section{Kesimpulan}

Kesimpulan yang dapat diambil dari pembahasan diatas yaitu, terkait dengan perlindungan musik atau lagu ini, negara memberikan perlindungan secara eksklusif melalui Undang-Undang Hak Cipta. Undang-Undang Hak Cipta telah memberikan perlindungan terhadap Hak Moral dan Hak Ekonomi dari pemilik atau pemegang Hak Cipta dari lagu tersebut. Pencipta lagu sudah mendapatkan perlindungan hukum sejak karyanya selesai dibuat, diketahui, didengar, dan dilihat oleh orang lain. Tetapi lebih baik jika dilakukan pencatatan terhadap hak cipta tersebut yang bertujuan untuk memudahkan si pencipta dalam membuktikan haknya dalam bentuk yang formal dan untuk memperoleh kepastian hukum siapa pemegang hak cipta tersebut. Penyelesaian sengketa disini dapat diselesaikan melalui dua cara. Yaitu melalui jalur non litigasi atau diluar pengadilan dan melalui jalur pengadilan atau litigasi. Penyelesaian melalui jalur nonlitigasi dapat dibagi menjadi beberapa bagian yaitu Konsultasi, mediasi, negosiasi, konsiliasi, dan arbitrase. Sedangkan jika melalui jalur litigasi, dapat ditempuh melalui dua cara yaitu melalui upaya perdata dan upaya pidana. Sanksi yang diterima jika terbukti melakukan pelanggaran dapat berupa kurungan dan denda sesuai dengan yang tercantum didalam Undang-Undang Hak Cipta. Sanksi yang terdapat di dalam Undang-Undang Hak Cipta dinilai sangat tepat untuk memberikan efek jera kepada pelaku pelanggaran agar tidak mengulangi perbuatannya kembali.

\section{DAFTAR PUSTAKA}

Buku : 
Firmansyah, Hery. Perlindungan Hukum Terhadap Merek: Panduan Memahami Dasar Hukum Penggunaan dan Perlindungan Merek. Media Pressindo, 2018.

Goldstein, Paul. Hak Cipta: Dahulu, Kini dan Esok. Yayasan Obor Indonesia, 1997.

Julia, J. Pendidikan Musik: Permasalahan dan Pembelajarannya. UPI Sumedang Press, 2017.

\section{Jurnal:}

Anindya, Fitria Trie Maytasari, and I. Wayan Wiryawan. "Upaya Hukum Dalam Penyelesaian Pelanggaran Dan Sengketa Hak Karya Cipta Musik." Kertha Semaya: Journal Ilmu Hukum.

Assa, Marybella Natasha. "Upaya Perlindungan Hukum Terhadap Hak Cipta Lagu dan Musik di Internet Menurut Undang-Undang Nomor 28 Tahun 2014." Lex Privatum 4, no. 1 (2016).

Dimyati, Agus. "Tinjauan Yuridis Terhadap Perlindungan Hak Cipta Dalam Penggunaan Karya Cipta Musik Dan Lagu Karaoke." Hukum Responsif Jurnal Hukum 7, no. 1 (2018).

Dewi, Anak Agung Mirah Satria. "Perlindungan Hukum Hak Cipta Terhadap Cover Version Lagu Di Youtube." Jurnal Magister Hukum Udayana (Udayana Master Law Journal) 6, no. 4 (2017): 508-520.

Fuad, Matari Nurfirdausyi. "KEPASTIAN HUKUM BAGI KONSUMEN TERHADAP KERUGIAN YANG DITIMBULKAN OLEH DRIVER GO-JEK BERDASARKAN HUKUM PERLINDUNGAN KONSUMEN." LITIGASI 19, no. 1 (2019).

Indriani, Iin. "Hak Kekayaan Intelektual: Perlindungan Hukum Terhadap Hak Cipta Karya Musik." Jurnal Ilmu Hukum 7, no. 2 (2018): 246-263.

Lopes, Fransin Miranda. "Penegakan Hukum Terhadap Pelanggaran Hak Cipta di Bidang Musik dan Lagu." Lex Privatum 1, no. 2 (2013).

Kurniawan, I. Gede Agus. "Pengaturan Penghentian Pemakaian Indikasi Geografis Pada Merek Terdaftar Oleh Pihak Lain Yang Tidak Berhak (Studi Komparatif Beberapa Negara)." Jurnal Magister Hukum Udayana (Udayana Master Law Journal) 2, no. 2 (2013).

Marlina, Tina, and Dora Kartika Kumala. "Perlindungan Hukum Terhadap Pencipta Lagu Yang Lagunya Dinyanyikan Ulang (Cover) Tanpa Izin Untuk Kepentingan Komersial Dalam Media Internet." Syntax Literate; Jurnal Ilmiah Indonesia 4, no. 11 (2019): 174-183.

Supasti, Ni Ketut. "Relevansi Hak Kekayaan Intelektual Dengan Hak Asasi Manusia Generasi Kedua." Jurnal Dinamika Hukum 14, no. 3 (2014): 518-527.

Septiana, Kadek Irman, and AA Gede Oka Parwata. "PERLINDUNGAN HUKUM TERHADAP PENCIPTA LAGU YANG LAGUNYA DINYANYIKAN TANPA IJIN BERDASARKAN UNDANGUNDANG HAK CIPTA." Kertha Semaya: Journal Ilmu Hukum 7, no. 2: 1-12.

Swari, P. Dina Amanda, and I. Made Subawa. "Perlindungan Hukum Lagu Yang Diunggah Tanpa Izin Pencipta Di Situs Youtube." Kertha Semaya: Journal Ilmu Hukum 6, no. 10 (2018): 1-15.

Pratista, I. Gusti Putu Andre, and Ida Ayu Sukihana. "Pelanggaran Hak Moral Karya Lagu/Musik dan Rekaman Suara dalam Praktik Penggunaan Hak Cipta." Kertha Semaya: Journal Ilmu Hukum (2014).

UTAMA, ARYA, TITIN TITAWATI, and ALINE FEBRYANI LOILEWEN. "PERLINDUNGAN HUKUM TERHADAP HAK CIPTA LAGU DAN MUSIK MENURUT UNDANG-UNDANG NOMOR 28 TAHUN 2004." GANEC SWARA 13, no. 1 (2019): 78-83. 
Yasa, Ade Hendra, and AA Ketut Sukranatha. "UPAYA HUKUM PENYELESAIAN SENGKETA KARYA CIPTA MUSIK." Kertha Semaya: Journal Ilmu Hukum 4, no. 3.

\section{Perundang-undangan :}

Kitab Undang-Undang Hukum Perdata (Burgerlijk Wetboek). Diterjemahkan oleh Subekti dan R. Tjitrosudibio. Jakarta : Pradnya Paramita, 2008.

Undang-Undang Nomor 28 Tahun 2014 Tentang Hak Cipta, Lembaran Negara Republik Indonesia Nomor 266 Tahun 2014, Tambahan Lembaran Negara Republik Indonesia Nomor 5599.

Undang-Undang Nomor 30 Tahun 1999 Tentang Arbitrase dan Alternatif Penyelesaian Sengketa, Lembaran Negara Republik Indonesia Nomor 138 Tahun 1999, Tambahan Lembaran Negara Republik Indonesia Nomor 3872. 